by-product of the soap industry has been ousted from the prominent position it formerly held in respect to the manufacture of high explosives. What appears to be a valuable suggestion was made recently by a member of the Council of the Pharmaceutical Society, Mr. J. C. Young, who, in an address on the subject to a branch meeting of the Society, suggested that manufacturers who introduced new compounds should not use sugar but some alternative for it. By this means there would be an avoidance of change of appearance and taste of the compound in the event of it becoming necessary to forgo the use of sugar.

\section{ORIGIN OF THE SOLAR SYSTEM}

$\mathrm{R}$.

A. LYTTLETON has now prepared a detailed R. defence of his theory of the origin of the solar system against various criticisms urged at different times (Mon. Not. Roy. Astro. Soc., 100, 7 ; May 1940). In the short compass of the present note it is im. possible to consider in detail the contents of the paper, which should be read by all interested in problems of cosmogony. A few outstanding points are worthy of special attention.

It will be recalled that the theory was first put forward in 1936 (Mon. Not. Roy. Astro. Soc., 96, 559; 1936). Luyten criticized various features of the theory, and, inter alia, pointed out that hydrogen would readily escape at high temperature from the filament from which the planets were evolved. Lyttleton shows that, while the lightest elements would escape from the filament or primitive planet, such gases would not necessarily escape from the sun. They would form a tenuous medium, possessed with angular momentum, through which the planets would move. As the planets would pick up lighter gases after their initial formation from the heavier elements, the presence of hydrogen on the major planets is no objection, as Luyten believed, to Lyttleton's theory.

Another important matter is the amount of energy required to remove the planetary material. Luyten and Hill pointed out that the energy necessary to generate the planets from the companion to the sun must have been so large that the visiting star would have required a velocity of the order of $100 \mathrm{~km}$. a second. In these circumstances the centre of the ribbon from which the planets were formed would have possessed a velocity far beyond the escape velocity relative to the sun. In the present paper, Lyttleton deals with some simple quantitative results and shows that in his reply in an earlier paper it was unnecessary to postulate so large a relative mass for the intruding star. In fact, there is no justification for assuming that the energy could be supplied only by a star of exceptionally high mass.

Other points are dealt with, such as the objection to the complexity of the theory, which, Lyttleton shows, is not a valid objection. Nor can the difficulties regarding the filament be urged as serious when it is remembered that the generally accepted views concerning the development of the filament were current before he propounded his theory, and hence he is not responsible for them. He admits at the end of the paper that, while his own theory is not really open to any objection, this does not preclude the possibility that other explanations of the origin of the solar system may be devised.

\section{APPOINTMENTS VACANT}

APPLICATIONS are invited for the foliowing appointments on or before the dates mentioned:

Part-time Thachers of Engingering Drawing (S.1), ElectroTEChNOLOGY (D.C.) (S.3), THEORY of MAChines (A.1), ENGINEERING DRAWING and DESIGN (A.2), ELEOTRICAL ENGINRERING-MRASURE-

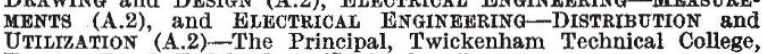
Egerton Road, Twickenham (September 4).

Assistant Secretary for Higher FddCATION-The Secretary for Education, County Offices, Aylesbury, Bucks (September 7).

DEPUTY DIRECTOR OF EDUCATION-The Director of Education, Education Offices, Union Street West, Oldham (September 7).

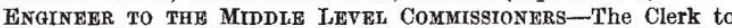
the Commissioners, Middle Level Offices, March, Cambs. (September 10).

\section{REPORTS AND OTHER PUBLICATIONS}

(not included in the monthly Books Supplement) Great Britain and Ireland Proceedings of the Royal Society of Edinburgh, Session 1939-1940.
Vol. 60, Part 2, No. 17: The Energy Levels of a Rotating Vibrator. By Dr. Tan Sandeman. Pp. 210-223. (Edinburgh : Robert Grant and Son, Ltd. ; London: Williams and Norgate, Ltd.) 18.3d. [128

\section{Other Countries}

Journal of the Federated Malay States Museums. Vol. 18, Part 4 : New Genera and Species of Malaysian Reduviidae (Part 1). By . C. E. Miller. Pp. 415-600. (Kuala Lumpur: F.M.S. Museum.) [98 Proceedings of the United States National Museum. Vol. 88, No. 3082: Revision of the Chalcid-Flies of the Tribe Chalcidini in America North of Mexico. By B. D. Burks. Pp. 237-354. Vol. 88, No. 3084: The Scolytid Beetles of the Genus Renocis Casey, with Descriptions of Nine New Species. By M. W. Blackman. Pp. 373402. Vol. 88, No. 3087: A Review of the Parasitic Crustacea of the Genus Argulus in the Collections of the United States National Museum. By O. Lloyd Meehean. Pp. 459-522 (Washington, D.C.: Govern-
ment Printing Officn.) [98
Memoirs of the Geological Survey of India. Vol. 70, Part 2, No. 2 : Attempt at the Correlation of the Ancient Schistose Formation of Peninsular India. By Sir Lewis Leigh Fermor. Pp. iv +219-324+ plates 2-4. (Calcutta: Geological Survey of India.) 1.12 rupees ;

Memoirs of the Geological Survey of India. Palaeontologia Indica, Series 9, Vol. 3, Part 3: The Jurassic Lamellibranch Fauna of Kuch (Cutch). By Dr. L. R. Cox. Pp. vi $+158+10$ plates. (Calcutta: (Cutch). By Dr. L. R. Cox. Pp. vi $+158+10$ plates. (Calcutta:
Geological Survey of India.) 9.10 rupees; $15 \mathrm{~s}$. Proceedings of the Second Session of the Indian Statistical Conference held in Lahore, January 1939 . Edited by P. C. Mahalanobis. Pp. ii + 168. (Calcutta: Statistical Publishing Society.) [98 Department of Public Instruction, Technical Education Branch, New South Wales. Technological Museum : Curator's Annual Report for Year ended 31st December 1939. Pp. 4. (Sydney : Government Annual Review of Biochemical and Applied Research in India.

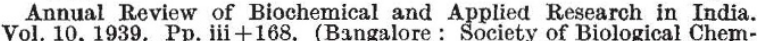
Vol. 10,1939 . Pp. $\mathrm{iii}+168$. (Bangalore : Society of Biological Chem-
ists.) 3 rupees ; 68 . U.S. Department of the Interior : Geologicar Survey. Bulletin 912 : Spirit Leveling in Utah, 1897-1938. Pp. iii $+222+2$ plates. 30 cents. Bulletin 916-C: Transit Traverse in Missouri. Part 3: East-Central Missouri, $1903-37$. Pp. $\mathrm{x}+297-460+\mathrm{xi}-\mathrm{xiv}+1$ plate. 20 cents. (Washington, D.C.: Government Printing Office.) [128

U.S. Department of the Interior: Geological Survey. WaterSupply Paper 841: Geology and Ground-Water Resources of the Harney Basin, Oregon. By A. M. Piper, T. W. Robinson and C. F . Park, Jr. ; with a statement on Precipitation and Tree Growth, by L. T. Jessup. Pp. vi $+190+20$ plates. 1 dollar. Water-Supply Paper 843: Floods of December 1937 in Northern California. By H. D. McGlashan and $\mathbf{R}$. C. Briggs. Pp. viii $+498+18$ plates. 60 cents. (Washington, D.C. : Government Printing Offee.) plates. 60 cents. Western Australia: Geological Survey. Bulletin No. 97: The Western Australia: Geological Survey. Bulletin No. 97: The Geology of the Yilgarn Goldfleld, South of the Great Eastern Railway. By H. A. Ellis ; with an Appendix by Dr. Dorothy Carroll on "SandPlain Soils from the Yilgarn Goldfleld”'. Pp. $192+7$ plates. (Perth :
Government Printer.)

Western Australia. Annual Progress Report of the Geological Survey for the Year 1938. Pp. $34+8$ plates. (Perth : Government Printer.)

American Philosophical Society held at Philadelphia for promoting Useful Knowledge Year Book 1939 January 1, 1939-Decomoting 1939. Pp 494. (Philadelphia. American Philosophical Society. [128 Field Museum of Natural History. Geological Series, Vol. 8, No. 1 A New Turtle of the Genus Podoenemis from the Cretaceous of Arkansas. By Karl P. Schmidt. Pp. 12. 15 cents, Zoological Series, Vol. 24, No. 14: A New Venezuelan Honey Creeper By Emmet R. Blake. Pp. 155-158, 10 cents. Zoological Series, Vol, 24, No 15: A New Savannah Sparrow from Mexico. By Sidney Camras. Pp. 159160. 10 cents. (Chicago: Field Museum of Natural History.) [138
[1 Industrial Research Bureau. Bulletins of Indian Industrial Research, No. 16: The Manufacture and Application of Liquid Gold. By Dr. Atma Ram, Dr. Karimullah and Dr. Lal C. Verman. Pp. 20. (Delhi : Manager of Publications.) 6 annas ; $7 d$. 